\title{
Squeeze casting results of aluminium alloys
}

Iva Nová, Jiří Machuta

Faculty of Mechanical Engineering, Department of Engineering Technology, Technical University of Liberec, Czech Republic, e-mail: iva.nova@tul.cz,jiri.machuta@tul.cz

The paper deals with a squeeze casting process. This process added a new knowledge in to research in the branch by crystallization of aluminium alloys. Due to this purpose there was designed a special tool, which was placed on hydraulic press. The squeeze casting was carried out on an aluminium alloy (AlSi12, with $12 \%$ silicon). The main aim was study of the aluminium alloy structure, which was established at a pressure of crystallizing melt. In this way of the material crystallization was produced a truncated cone part with the larger the base $\varnothing 100$ mm x $105 \mathrm{~mm}$ ). The structure of specimens was monitored on a light microscope and was evaluated by means of software NIS Elements. The main results of the pressure melt to fine crystalline structure, which is represented fine dendrites both on surface and in an interior parts of the processed material. The influence of this pressure on the mechanical properties was monitored too.

Keywords: alloy AlSi12, pressure, crystallization, structure

\section{Acknowledgement}

This paper was supported by the project TUL SGS 2822.

\section{References}

[1] GHOMASHCHI, M. R. VIKHROV, A. (2000). Squeeze casting: an overview, J. Mater.Process. Technol. 101, pp. 1-9.

[2] MORTON, J. R., BARLOW, J. (1994). Squeeze casting: from a theory to profit and future, J. Inst. Brit. Foundryman, Part 1, 87, pp. 23-28.

[3] LEE, J. H., KIM, H.S. et al. (1999). Effect of die geometry on the microstructure of indirect squeeze cast and gravity die cast 5083 wrought Al alloy and numerical analysis of the cooling behavior, J. Mater. Process. Technol. 96 (1999), pp. 188-197.

[4] ROLALAND, T. et. al. (1993). Strain induced macrosegregation in Squeeze cast Al-Mg and Al-Si alloys. Materials Science and Engineering, A 173, 1993, pp. 267-270.

[5] YANG, L. J. (2003). The Effect of Casting temperature on the Properties of Squeeze Casting Aluminium and Zinc Alloys. Journal of Materials Processing Technology. Vol. 140, Iss.1-3, pp. 391- 396.

[6] YOUN, S. W., KANG, C, G. (2004). Thermal /Fluid Solidification Analysis of Automobile part by Horizontal Squeeze Casting Process and Experimental Evaluation. Journal of Materials Processing Technology. Vol. 146, Issue 3, 2004, pp. 294 - 302.

[7] MICHNA, Š. (2010). Legování hliníkových slitin pomocí chromových legovacích tablet. Strojírenská technologie, roč. XV, č. 1, pp. 22 -26, ISSN 1211-4162 (in Czech).

[8] Michna, Š, Vojtěch, D. (2008). Problematika kvality Al taveniny při lití automobilových disk. Strojírenská Technologie, roč. XIII, č. 3, pp. 17 - 23. ISSN 1211-4162 (in Czech).

[9] HAZLINGER, M. et. al. (2010). Degradačné procesy a predikcia životnosti materiálov. [Degradation processes and materials life prediction]. 1. vyd. Slovenská technická univerzita Bratislava, 2010 (in Slovak).

[10] LIPINSKI, T. (2011). Microstructure and Mechanical Properties of the AlSi13Mg1CuNi Alloy with Ecological modifier. In: Manufacturing Technology December 2011, Vol. 11, No. 11 pp. 40-44. ISSN 1213-2489.

[11] GREGER, M.,WIDOMSKÁ, M. (2011). Analysis of influence of structure on mechanical properties of AlSiMg aluminium alloy processed by ECAP. Manufacturing Technology XI, December 2011, Vol. 11, No. 11 pp. 17 22. ISSN 1213-2489.

[12] BORKOWSKI, S., STASIAK-BETLEJEVSKA, R., NÁPRSTKOVÁ, N. (2011). The Kaizen philosophy in the aluminium products improvement. In: Manufacturing Technology, December 2011, Vol. 11, No. 11 pp. 2-5. ISSN 1213-2489. 